\title{
STUDENTS' PERSPECTIVES ON USING TELEGRAM MESSENGER AS A LEARNING MEDIA
}

\author{
Sri Wahyuni \\ Universitas Islam Riau \\ wahyunis@edu.uir.ac.id
}

\begin{abstract}
A learning media is very important to support a course to achieve the learning objective. This study deals with how are students' perspectives on using Telegram Messenger that used as a learning media at English Study Program of Universitas Islam Riau. This research was a descriptive qualitative research. It was conducted at Universitas Islam Riau at Jalan Kaharuddin Nasution No. 133 Pemberhentian Marpoyan, Pekanbaru-Riau from January until May 2017 with the samples were the fifth semester students at English Study Program. The research instrument in this research was a questionnaire that consists of 20 statements of (1) perceived usefulness (2) perceived ease to use (3) attitude toward using (4) actual system use. Further, to get the information related to four indicators in this research, the researcher employed likert scale, 5 was given for strongly agree (SA), 4 for agree (A), 3 for undecided (U), 2 for disagree (D), and 1 for strongly disagree (SD). The questionnaire used close-ended question in online questionnaire, asking the respondent to get students' perspective on using Telegram Messenger by checking one check box in Survey Monkey. The students' perspectives in perceived ease of use for strongly agree which was 35\%, perceived usefulness for strongly agree was $22 \%$, attitude toward usage for strongly agree was $30 \%$, actual system use for strongly agree was $19 \%$, actual system use for strongly agree was $19 \%$. In other words, respondent positively responded.
\end{abstract}

Keywords: Students' Perspectives, Telegram Messenger, Survey Monkey

\section{INTRODUCTION}

Every way of looking at every phenomenon and the reality around the people, not only can be seen, interpreted and conceptualized from one point of view, because basically every phenomenon has multiple perspectives. People can analyze the phenomenon or the problem by using their perspectives. According to
Sumaatmadja and Winardit (1999), perspective is the way of looking of a person or how one behaves towards a phenomenon or problem occurrence. So people who has perspective think broadly and wise in resolve their problem or issue, because people never think in narrow view, people cannot see just one perspective to analyze the issue. To open the eyes widely and 
think broadly in multiple points of view based on phenomena that occur.

Someone who had good perspectives will be easy to interact with another people, but would not easy for someone who has narrow

view, the way behave in new situation or circumstance. One people had own perspective about something and cannot be duplicated by another people. Everyone had different perspectives of something, which meant someone who had a broadly and wise perspective people can see in a lot of point of view and would understand and easy socialize with people.

People must socialize with another, because human being as social beings, who need someone in this world. Interaction and socialization were the activity that happened in every day. People met someone, talk, and share feeling and happiness. But sometimes, interaction was not directly face to face, technology helped in communication with family or friend who could not be met. In this globalization era which everything was under control.

Technology and multimedia have expanded rapidly. One of those are Including internet which everyone could access to find anything. Technology and internet have offered opportunities for activity in daily needs. Take the case of technology which was used by people was mobile phone.
Mobile phone was a tool to communicate by other by voice but became fast change multi-function as minicomputer with wireless networking with high quality camera, good application and multimedia, so people experienced the function of whole technology in both of hand. Simply and flexibility were the reason people used mobile phone and brought every time and easy to keep in the pocket or bag.

Mobile phones have been transformed become the most popular technology. Not only as the tools for communication but also for entertainment and socialization to another people. Some people used smart phone to help in working, with a good application has entertained when got free time. The most people used the mobile phone for socialization with another people or for communicating with someone who stay in another country. People shared a good story or tutorial in social media to showed existence, because every people interacted with another people.

The advantages the mobile phone could be used in educational side. Technologies have also helped to promote and maintain the education standards. These tools allowed multiple users to participate collaboratively rather than working alone. Technology offer many functions that appeal to educators who are looking to extend learning beyond the classroom 
(Haygood, Garner, \& Johnson (2012); Koole (2009); Januszewski \& Molenda (2008); Seels \& Richey (1994:12)). One of useful application in mobile phones which could be helped students in educations in Telegram Messenger. This service was accessible through any mobile device with Internet capabilities including free apps providing a simple way.

By using telegram messenger teachers were able to message to student faster because Telegram Messenger one cloud system which sent message faster, made a group chat or students, send the file such us videos, pdf which size more than 1,5 GB. People were able to access free without any advertisement. Teacher got easier to communicate to students even in the free class. The researcher assumed that Telegram Messenger as educational media which was used in teaching and learning process, especially in English for specific purposes.

One of the English Specific Purposes was English for office as a subject in the fifth semester students of English department of UIR based of newest curriculum. English for office focused on using English in letter. English for Office was the one of subjects in English Department of FKIP that was taken in fifth semester to fulfill system credits. In this subject, the fifth semester students learned about how to use English in the office activities, especially to make formal or informal letter. When student in educational organization, where students required writing formal letter to another organization students were good at writing.

In English for Office class lectures used $25 \%$ portion of time allocation in using Telegram Messenger, students had a group class in Telegram Messenger to communication and sharing videos, material and discussion about material. So lectures got easy to share information about material and homework for students. Then, Lectures used $75 \%$ portion of time allocation to have face to faces in the class, after material has been shared in Telegram Messenger students could discuss in the class related materials. If students had question or find problems could be discussed with lectures or friends. As stated by Finn \& Bucceri, (2004), combining e-learning and traditional method will create an educational environment. E-learning ensure flexibility and efficient and could not be found in traditional method which focus on face-to-face and interaction between students and teacher.

Thorne (2003) also stated that as "the way of meeting the challenges of tailoring learning development to the needs of individuals by integrating the innovate and technological advance offered by online learning with the interaction and participation offered in 
the best of traditional learning". Blended learning focused on technology multimedia, computerized, virtual technology, and internet that used in traditional classes. So student could access the information by face-toface in the class or by offline and online by connected to the internet.

The main reason, researcher has chosen this title because human lived in technology era, where everything was operate with technology such as gadget, internet and people did not avoid using that. As stipulated by Permendikbud no.49/2014 article 1:14 about Lecturers are professional educators and scientists with the primary task of transforming, developing, and disseminating science, technology through education, research, and devote onto the community. So, in education lectures must utilize existing technologies to support learning material. The implementation of technology in education has been done by teacher. Teachers were able to use technology as media in education. As stated by Buckingham (2003), Briggs in Aniqotunnisa (2013:10), Cornellas cited in Fedorov (2006) defined media education is deals with all communication media and includes printed word and graphics, the sound, the still as well as moving images, delivered on any kind of technology".

Besides that, Lack of using Telegram Messenger in academic purposes. Telegram Messenger was not familiar application in student's environment. Telegram Messenger has been replaced by another social media or application. Some students were not interested in using Telegram Messenger although this application has some more strengths than others.

Based on the reason that explained above, the researcher has conducted the research that was to investigate the students' perspective in using telegram.

\section{METHOD}

This research was a descriptive qualitative research. Qualitative research is research in which narrative or visual data was collected to describe social settings (Slavin, 2007). In this case, the researcher wanted to survey the fifth semester students' perspectives in using Telegram Messenger in English for Office subject in English Program of FKIP UIR. This research had one variable that is, students' perspectives on using Telegram Messenger on fifth semester of English for office class.

Instrument of this research was electronic survey. According to Lazar and Preece, 1999; Oppermann 1995; Saris 1991 perhaps three most common reasons for choosing an e-survey over traditional paper- and - pencil approaches are decreased coast, faster response time, increase response rate. The researcher used online 
questionnaire through survey monkey application to analyze student's perspective in using Telegram Messenger.

The questionnaires were used and adapted from Chuttur (2009) that consist of 20 statements of (1) perceived usefulness (2) perceived ease to use (3) attitude toward using (4) actual system use. In addition, to get the information related to four indicators in this research, the researcher has employed likert scale, 5 is given for strongly agree (SA), 4 for agree (A), 3 for undecided (U), 2 for disagree (D), and 1 for strongly disagree (SD). The researcher used close-ended question in online questionnaire, asking the respondent to get students' perspective on using Telegram Messenger by checking one check box in Survey Monkey.

\section{FINDING AND DISCUSSION}

After administering the data to the students, based on the data the students' perspectives was positively responded. The detail information of the result is in the following.

\section{Figure 1 Perceived Ease of Use}

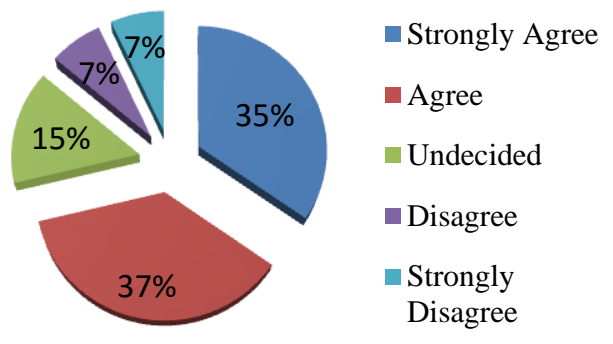

Figure 1 showed that the students' perspectives in perceived ease of use. For strongly agree, the respondent was $35 \%$, overall positively responded. For agree, the respondent percentage was $37 \%$, overall positively responded. For undecided, the respondent percentage was $15 \%$. For disagree, the respondent percentage was $7 \%$. For strongly disagree, the respondent percentage was $7 \%$.

\section{Figure 2 Perceived Usefulness}

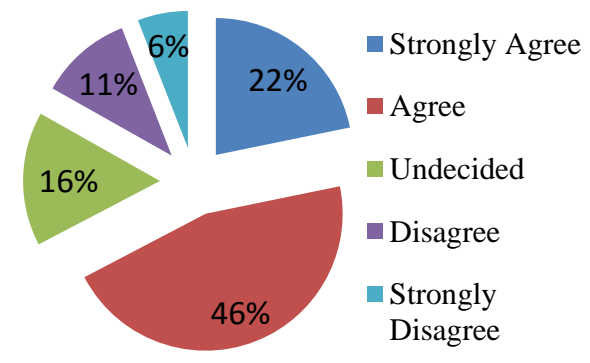

Next, the students' perspectives in perceived usefulness can be seen on figure 2. For strongly agree, the respondent percentage was $22 \%$, 
overall positively responded. For agree, the respondent percentage was $46 \%$, overall positively responded. For undecided, the respondent percentage was $16 \%$. For disagree, the respondent percentage was $11 \%$. For strongly disagree, the respondent percentage was $6 \%$.

\section{Figure 3 Attitudes toward Usage}

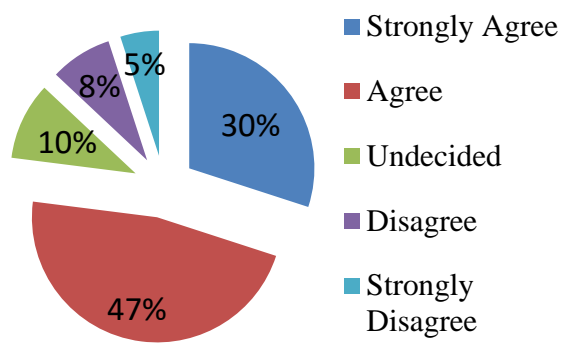

From figure 3 , it can be seen that the students' perspectives in attitude toward usage. For strongly agree, the respondent percentage was $30 \%$, overall positively responded. For agree, the respondent percentage was $47 \%$, overall positively responded. For undecided, the respondent the percentage was $10 \%$. For disagree, respondent percentage was $8 \%$. For strongly disagree, the respondent percentage was $5 \%$.
Figure 4 Actual System Use

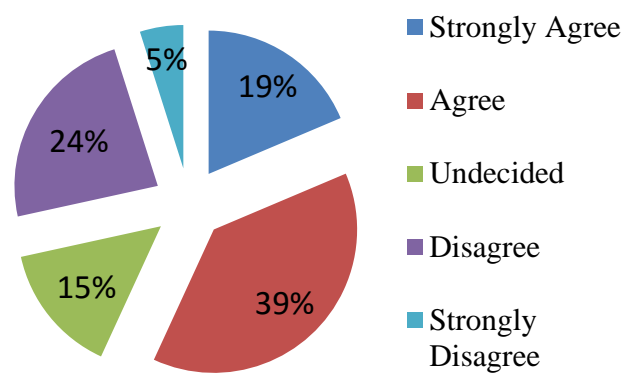

The last indicator, it can be seen from figure 4 showed for strongly agree, the respondent percentage was $19 \%$, overall positively responded. For agree, the respondent percentage was $39 \%$, overall positively responded. For undecided, respondent percentage was $15 \%$. For disagree, the respondent percentage was $24 \%$. For strongly disagree, the respondent percentage was $5 \%$.

Based on explanation mentioned, it can see that the higher and lower percentage for each indicator of using Telegram Messenger in English for office class. For perceived ease of use, the higher percentage is agree $37 \%$, and lower percentage is strongly disagree $7 \%$. For perceived usefulness, the higher percentage is agree $46 \%$, and lower percentage is strongly disagree 6\%. For attitude toward usage, the higher percentage is agree $47 \%$, and lower percentage is strongly disagree 5\%. And for actual system use, the higher percentage is 
agree 39\% and lower percentage is strongly disagree $5 \%$.

\section{CONCLUSION}

This research has purpose to describe students' perspective on using Telegram messenger as a learning media at the fifth semester students of English Language Education of Teacher Training and Education Faculty Universitas Islam Riau. Based on the finding of this research, it can be concluded that Telegram Messenger can be media in teaching and learning but they often use Telegram Messenger in daily media communication. It was shown by the respondent's percentages that lower than $50 \%$ of them agree to use Telegram Messenger.

\section{REFERENCES}

Aniqotunnisa,

Siti.

2013.Pengembangan Media

Pembelajaran Quis interatif Nahwu Berbasis Makro Media Flash 8 sebagai sumber Belajar Mandiri di Madrasah Tsanawiyah Ibnul Qoyim Putra Kelas VIII. Jurusan Pendidikan Bahasa Arab.

Buckingham, D. (2003). Media Education: Literacy, Learning and Contemporary Culture. Cambridge, UK: Polity Press, 219p.

Chuttur M.Y. (2009). "Overview of the Technology Acceptance Model:
Origins, Developments and Future Directions ," Indiana University, USA . Sprouts: Working Papers on Information Systems, 9(37). http://sprouts.aisnet.org/9-37

Fedorov, A. (2006). Media Education Must Become Part and Parcel of the Curriculum. Interview in Thinking Classroom, 2006. Vol.7, Number 3, pp. 25-30.

Finn, A., \& Bucceri, M. (2004). A case study approach to blended learning, retrieved January 15, 2008 from http://www.centra.com/download /whitepapers/CaseStudy_Blended Learning.pdf

Haygood, E., Garner, R., \& Johnson, S. (2012). Blended Learning: Using Web 2.0S to Enhance Classroom Instruction. Interlink Alliance. Retrieved October 10, 2013, from http://www.cehs.ohio.edu/

Januszewski\& Molenda. 2008. Instructional Technology and Media for Learning.New Jersey:Prentice Hall.

Koole, M. (2009). A Model for Framing Mobile Learning. Athabasca University: Canada.

Lazar, J., \& Preece, J.(1999). Designing and Implementating web-based surveys. Journal of Computer Information Systems, 39(4), 63-67. 
Oppermann,M.(1995). E-mail Surveys: Potentials and Pitfall. Marketing Research, 7(3), 28.

Saris, W.E. (1991). Computer-Assisted Interviewing, 80. Newbury Park: Sage.

Seels,B.B and Richey,R.C.1994. Intructional Technology: The Definition and Domain of the Field. Washington, DC.:Association for Educational Communication and Technology.

Slavin, R. (2007). Educational research in an age of accountability. Boston: Pearson Education.

Sumaatmadja, N. dan Wihardit, K. (1999). Persfektif Global. Jakarta: Universitas Terbuka Depdikbud.

Thorne, K. (2003). Blended learning: How to integrate online and traditional learning, London: Kogan Page. 